Article

\title{
The Antifungal Activity of Functionalized Chitin Nanocrystals in Poly (Lactid Acid) Films
}

\author{
Asier M. Salaberria ${ }^{1}$, Rene H. Diaz ${ }^{1}$, María A. Andrés ${ }^{1}$, Susana C.M. Fernandes ${ }^{2, *}$ and \\ Jalel Labidi ${ }^{1, *}$ \\ 1 Biorefinery Processes Research Group, Department of Chemical and Environmental Engineering, \\ Faculty of Engineering, University of the Basque Country (UPV/EHU), Pza. Europa 1, \\ 20018 Donostia-San Sebastian, Spain; asier.martinez@ehu.eus (A.M.S.); \\ renealexander.herrera@ehu.eus (R.H.D.), marian.andres@ehu.eus (M.A.A.) \\ 2 CNRS/Université de Pau et des Pays de l'Adour, Institut des Sciences Analytiques et de Physico-Chimie \\ pour l'Environnement et les Materiaux, UMR 5254, 2 Av. Pdt Angot, 64053 Pau, France \\ * Correspondence: susana.fernandes@univ-pau.fr (S.C.M.F.); jalel.labidi@ehu.es (J.L.); \\ Tel.: +33-540-175-015 (S.C.M.F.); +34-943-017-178 (J.L.)
}

Academic Editor: Jun-ichi Anzai

Received: 4 April 2017; Accepted: 12 May 2017; Published: 18 May 2017

\begin{abstract}
As, in the market, poly (lactic acid) (PLA) is the most used polymer as an alternative to conventional plastics, and as functionalized chitin nanocrystals (CHNC) can provide structural and bioactive properties, their combination sounds promising in the preparation of functional nanocomposite films for sustainable packaging. Chitin nanocrystals were successfully modified via acylation using anhydride acetic and dodecanoyl chloride acid to improve their compatibility with the matrix, PLA. The nanocomposite films were prepared by extrusion/compression approach using different concentrations of both sets of functionalized CHNC. This investigation brings forward that both sets of modified CHNC act as functional agents, i.e., they slightly improved the hydrophobic character of the PLA nanocomposite films, and, very importantly, they also enhanced their antifungal activity. Nonetheless, the nanocomposite films prepared with the CHNC modified with dodecanoyl chloride acid presented the best properties.
\end{abstract}

Keywords: poly(lactic acid); chitin nanocrystals; nanocomposites; barrier properties; fungal inhibition

\section{Introduction}

Among the available biodegradable polymers in the market, poly(lactic acid) (PLA) is the most used as a sustainable alternative to conventional plastics [1-4]. Lactic acid can be produced through microbial fermentation of agricultural by-products, namely corn, sugar beets, wheat and potato starch $[1,4,5]$; and PLA, which is an aliphatic thermoplastic polyester, can be obtained by polymerization of lactic acid monomers (hydroxyl carboxylic acids). Because of its properties, namely good mechanical strength and stiffness, UV stability and gloss, PLA is often comparable to polystyrene and polypropylene. Thus, increasing attention in the design and development PLA-based materials for food packaging, biomedical devices and automotive industry has been observed [6-8].

Similar to petrochemical derivatives, several strategies have been developed to improve the structural and/or functional properties of the polymer-based materials from renewable resources, including the incorporation of fillers. Natural fillers, such as nanofibers and nanocrystals from cellulose and chitin, and nanocrystals from starch are gaining considerable interest because of their abundance, chemical structure, low toxicity and biodegradability [9-16]. Moreover, chitin nanofillers provide antifungal or antibacterial properties [17-19]. 
Chitin is a crystalline high molecular weight linear polysaccharide consisting of $\beta-(1 \rightarrow$ 4)-2-acetamido-2-deoxy-D-glucopyranose repeating units, which is found in the crustacean shells, insect cuticles and in the cell walls of fungi, yeast and green algae. It occurs as a highly-organized micro- and nano-fibril structure increasing from the nanometer to the millimeter scale [20]. These fibrils form highly crystalline regions and disordered (amorphous) regions that can be turned in nanocrystals via top-down methods such as acid hydrolyses by dissolving the amorphous regions [18,21-24].

Nonetheless, the use of natural nanofillers, including nanochitin, on composite materials presents some drawbacks, in particular, their high polar character is responsible for a very low interfacial compatibility with common thermoplastic matrices, including PLA. Consequently, different approaches have been employed to overcome this issue $[25,26]$. Among them, the surface acylation of the natural nanofillers by the introduction of hydrophobic functional groups under heterogeneous conditions seems to be an efficient way to solve the compatibility issue [9,27-32].

Thus far, few studies regarding the use of chitin nanofillers as reinforcing agents in PLA matrices have been described in literature [25,26,33-36]. Following our interest in the preparation of chitin nanofillers-based materials $[18,20-23,37,38]$, the present study goes a step further than the use chitin nanofillers as reinforcing agents. The aim of this work was to improve the compatibility of chitin nanocrystals with PLA matrix and evaluate their behavior as functional agents for potential use as active food packaging.

\section{Materials and Methods}

\subsection{Materials}

Cervimunida johni lobster (known as yellow lobster) wastes in the form of powder were kindly supplied by Antartic Seafood S.A. (Coquimbo, Chile). Poly(lactic acid) (PLA, L-poly-lactide content is $\geq 99 \% w / w)$ with $\mathrm{Mw}$ of $180,000 \mathrm{~g} \mathrm{~mol}^{-1}$ in the form of pellets was kindly provided by Futerro S.A. (Celles, Belgium). Dodecanoyl chloride acid (98.0\%) was purchased from Aldrich. Hydrochloric acid ( $\mathrm{HCl}$, ACS reagent, $37.0 \%)$, sulfuric acid $\left(\mathrm{H}_{2} \mathrm{SO}_{4}\right.$, ACS reagent, $\left.\geq 95 \%\right)$, acetic anhydride $\left(\mathrm{Ac}_{2} \mathrm{O}\right.$, ACS reagent, $\geq 98.0 \%$ ), dimethylformamide (DMF, anhydrous, 99.8\%), acetone (analytical standard, $\geq 99 \%$ ), ethanol (analytical standard, 70\%) and pyridine (ACS reagent, $99 \%$ ) were purchased by Panreac (Barcelona, Spain). All reagents were used as received with exception of pyridine that was purified by distillation over sodium hydroxide.

\subsection{Chitin Extraction}

$\alpha$-Chitin $(\mathrm{CH})$ was extracted from yellow lobster wastes according our previous works [18,21-23]. Three main steps were applied in the following sequence: deproteinization-removal of proteins in a solution of $2 \mathrm{M} \mathrm{NaOH}$ at room temperature for $24 \mathrm{~h}$; demineralization-removal of minerals $\left(\mathrm{CaCO}_{3}\right)$ in a solution of $2 \mathrm{M} \mathrm{HCl}$ at room temperature for $3 \mathrm{~h}$; and decolorization-extraction of pigments and lipids using acetone followed by ethanol under reflux for $6 \mathrm{~h}$. Afterwards, $\alpha$-chitin was filtered and washed with deionized water twice. The resulting $\alpha$-chitin was dried at $60.0 \pm 0.5^{\circ} \mathrm{C}$ in an oven overnight. The degree of $\mathrm{N}$-acetylation was found to be $96 \%$ by ${ }^{13} \mathrm{C}-\mathrm{NMR}$ [39].

\section{3. $\alpha$-Chitin Nanocrystals Extraction}

Chitin nanocrystals (CHNC) were isolated from the obtained $\alpha$-chitin based on our previous work [18,21-23] adapted from the method developed by Paillet et al. [24]. To hydrolyze the amorphous regions of chitin, $\alpha$-chitin powder was dispersed in a solution of $3 \mathrm{M} \mathrm{HCl}$ at $100 \pm 2{ }^{\circ} \mathrm{C}$ and left for 90 min under vigorous stirring and refluxing. After acid hydrolysis, the obtained suspension was dispersed in deionized water and washed by centrifugation. This procedure was repeated three times. The suspension was then dialyzed changing deionized water every $12 \mathrm{~h}$ until $\mathrm{pH} 6$. Then the suspension was subjected to ultrasonic treatment for $10 \mathrm{~min}$ (Vibracell 75043 from Bioblock Scientific) to disintegrate chitin nanocrystal aggregates and obtain a homogeneous suspension. Finally, chitin 
nanocrystals were filtered to get a final suspension of $4 \mathrm{wt} \%$ and stored at $4{ }^{\circ} \mathrm{C}$ before used. $\mathrm{CHNC}$ presented a rod-like morphology with average wide of $60 \mathrm{~nm}$ and length of $300 \mathrm{~nm}$. Their degree of acetylation was estimated to be $92 \%$ by ${ }^{13}$ C-NMR spectroscopy [39] and crystallinity index to be $89 \%$ using the method of Focher et al. [40].

\subsection{Surface Functionalization of $\alpha$-Chitin Nanocrystals}

\subsubsection{Acylation with Acetic Anhydride}

The acylation of CHNC using acetic anhydride and sulfuric acid as catalyst was adapted from the method used by Frisoni et al. [41] (Figure 1a).

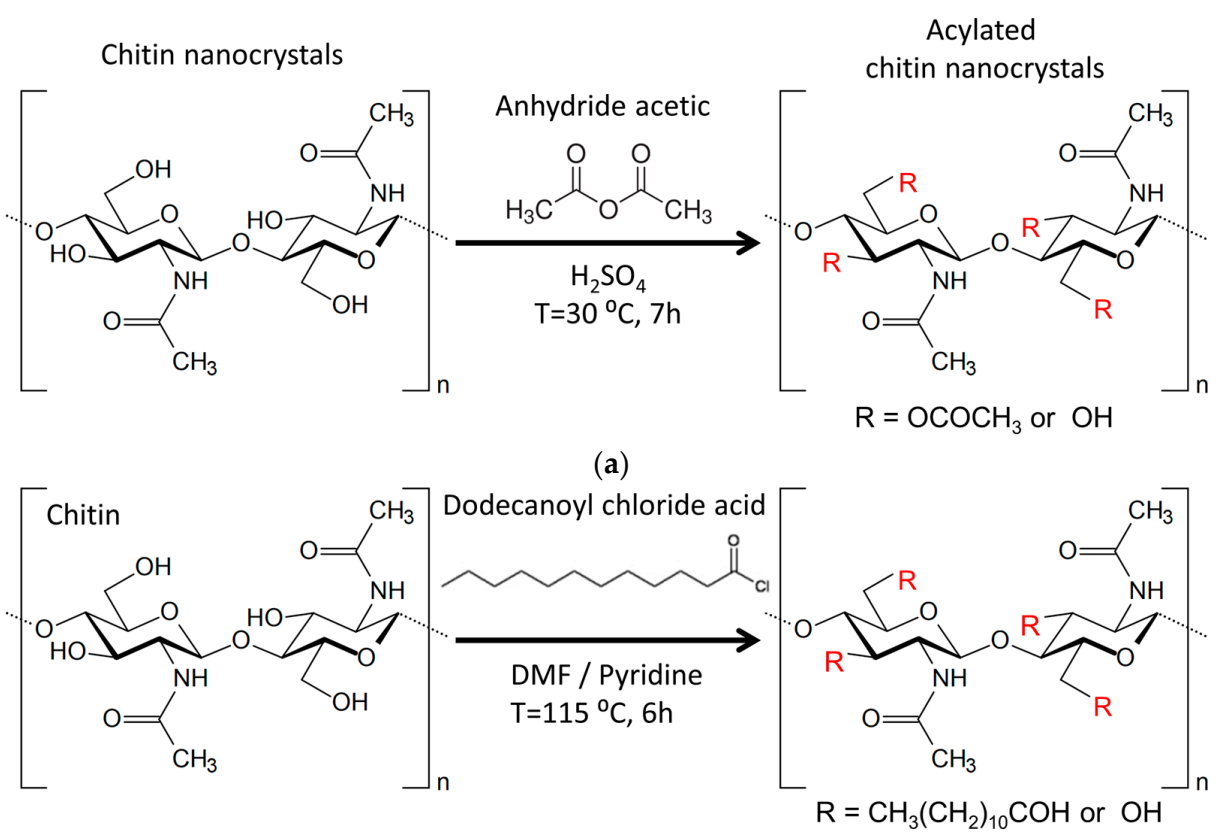

(b)

Figure 1. Scheme representing the heterogeneous chemical functionalization of chitin nanocrystals using: anhydride acetic (a); and dodecanoyl chloride acid (b).

Never dried CHNC (6 wt \% suspension in water) were submitted to solvent exchange to acetone via ethanol as intermediate solvent, with three dispersion/filtration sequences for each solvent $(50 \mathrm{~mL})$, and then in acetic anhydride $(50 \mathrm{~mL})$ with two dispersion/filtration sequences for $15 \mathrm{~min}$.

Afterwards, CHNC were dispersed in $15 \mathrm{~mL}$ of acetic anhydride containing $3.6 \mathrm{wt} \%$ sulfuric acid $(0.2 \mathrm{~mL})$ of the dry chitin weight. The reaction mixture was stirred at $30{ }^{\circ} \mathrm{C}$ for $7 \mathrm{~h}$. At the end of the reaction, the acylated chitin nanocrystals $\left(\mathrm{C}_{2} \mathrm{CHNC}\right)$ were filtered and sequentially washed with acetone and ethanol. To remove residual trace of acetic anhydride and other impurities, the $\mathrm{C}_{2} \mathrm{CHNC}$ were Soxhlet extracted with ethanol overnight and finally dried at $60{ }^{\circ} \mathrm{C}$ for $24 \mathrm{~h}$.

\subsubsection{Acylation with Dodecanoyl Chloride Acid (Fatty Acid)}

The acylation of CHNC using dodecanoyl chloride acid was carried out according the method described by Freire et al. [42] (Figure 1b). Dodecanoyl chloride acid (1 eq. relative to the total $\mathrm{OH}$ groups of chitin) was placed in a $250 \mathrm{~mL}$ round-bottom flask. DMF (100 mL), pyridine and CHNC $(2 \mathrm{~g})$ were then added and maintained under stirring at $115^{\circ} \mathrm{C}$ for $6 \mathrm{~h}$. After esterification, the mixture was filtered and washed with DMF, acetone and ethanol. To remove any residual trace of fatty acid, acylated chitin nanocrystals $\left(\mathrm{C}_{12} \mathrm{CHNC}\right)$ were Soxhlet extracted with ethanol overnight and finally dried at $60{ }^{\circ} \mathrm{C}$ in an oven for $24 \mathrm{~h}$. 


\subsection{Preparation of $P L A / C_{2} C H N C$ and $P L A / C_{12} C H N C$ Nanocomposite}

$\mathrm{PLA} / \mathrm{C}_{2} \mathrm{CHNC}$ and PLA $/ \mathrm{C}_{12} \mathrm{CHNC}$ nanocomposites were prepared by compression molding approach as following:

(1) PLA pellets were dissolved in chloroform $\left(10 \mathrm{~mL} \mathrm{~g}^{-1}\right)$ into a $250 \mathrm{~mL}$ glass beaker.

(2) Different amounts (i.e., 0.5, 1.0 and $2.0 \mathrm{wt} \%$ ) of each $\mathrm{C}_{2} \mathrm{CHNC}$ and $\mathrm{C}_{12} \mathrm{CHNC}$ sets were added in the different glass beaker.

(3) The mixtures were stirred for $5 \mathrm{~min}$ and then left at $30^{\circ} \mathrm{C}$ for 1 day to evaporate the solvent.

(4) After solvent evaporation, the PLA $/ \mathrm{C}_{2} \mathrm{CHNC}$ and PLA $/ \mathrm{C}_{12} \mathrm{CHNC}$ mixtures were extruded using a HAAKE MiniLab micro compounder at $180 \pm 2{ }^{\circ} \mathrm{C}$ and $120 \mathrm{rpm}$.

(5) Subsequently, the nanocomposites were molded by compression using a Metrotec press at $190{ }^{\circ} \mathrm{C}$ and 50 bar for $1 \mathrm{~min}$, followed by fast cooled.

(6) Finally, the samples were kept at $50 \%$ relative humidity (RH) and $25 \pm 2{ }^{\circ} \mathrm{C}$ for $72 \mathrm{~h}$ before being tested.

Samples identification is listed in Table 1.

Table 1. Identification of the PLA $/ \mathrm{C}_{2} \mathrm{CHNC}$ and PLA $/ \mathrm{C}_{12} \mathrm{CHNC}$ samples.

\begin{tabular}{ccc}
\hline Sample Identification & Acylation & CHNC (wt \%) \\
\hline PLA & - & - \\
PLA/C 20.5 & Acetic anhydride & 0.5 \\
PLA $/ C_{2} 1$ & Acetic anhydride & 1 \\
PLA $/ C_{2} 2$ & Acetic anhydride & 2 \\
PLA/C 120.5 & Dodecanoyl chloride acid & 0.5 \\
PLA $/ C_{12} 1$ & Dodecanoyl chloride acid & 1 \\
PLA $/ C_{12} 2$ & Dodecanoyl chloride acid & 2 \\
\hline
\end{tabular}

\subsection{Physicochemical and Morphological Characterization}

Attenuated total reflection Fourier transform infrared spectroscopy (ATR-FTIR) spectra were recorded on a Nicolet Nexus 670 equipped with a KRS- 5 crystal of refractive index 2.4 and using an incidence angle of $45^{\circ}$. The spectra were taken in a transmittance mode in the wavenumber range of $750-4000 \mathrm{~cm}^{-1}$, with resolution of $4 \mathrm{~cm}^{-1}$ and after $128 \mathrm{scan}$ accumulations. The spectra were normalized using the software Omnic.

X-ray diffraction patterns were collected using a Philips X'pert Pro automatic diffractometer using $\mathrm{Cu}-\mathrm{K} \alpha$ radiation operating at $40 \mathrm{kV}$ and $40 \mathrm{~mA}$ over the angular range of 5 to $40^{\circ} 2 \theta$ (step size $=0.04$ and time per step $=353 \mathrm{~s}$ ) at room temperature. The crystallinity index (C.I.) of chitin nanocrystal samples was calculated as follows (Equation (1)) [40,43]:

$$
\text { C.I. }(\%)=\left[\left(I_{110}-I_{a m} / I_{110}\right] \times 100\right.
$$

where $I_{110}$ is the maximum intensity (arbitrary units) of the 110 crystallographic plane and $I_{a m}$ is the amorphous portion diffraction, which usually is found about $2 \theta=12.5-13.5^{\circ}$.

Atomic force microscopy (AFM) images were performed in a Dimension 3100 NanoScope IV (Veeco, Santa Barbara, CA, USA). The images were scanned in tapping mode under ambient conditions using silicon nitride cantilevers having a tip nominal radius of $10 \mathrm{~nm}$ at a frequency of $1 \mathrm{~Hz}$. Chitin nanocrystal samples were first well diluted in water and sonicated for $5 \mathrm{~min}$ until colloidal suspension (Vibracell 75043 from Bioblock Scientific). Then a drop of the suspension was casted on to a mica piece, which is late subjected to a spin coating equipment (Specialty coating systems INC, Spin Coater model P6700 series) at $2000 \mathrm{rpm}$ for $2 \mathrm{~min}$. The dimensions of nanocrystals were calculated by measuring 100 different nanocrystals.

The light transmittance spectra of the materials were measured using a Shimadzu (Kyoto, Japan) UV-3600 UV-VIS-NIR spectrophotometer. Spectra were recorded at room temperature in steps of $1 \mathrm{~nm}$, in the range $400-700 \mathrm{~nm}$. 
Contact angle measurements were performed at room temperature using Dataphysics OCA20 Contact Angle System (Filderstadt, Germany). Three different liquids, with different dispersive and polar surface tensions (water, diiodomethane and ethylene glycol), were used to determine the surface energy of the samples following the Owens and Wendt approach [44]. To perform the measurements, $50 \pm 5 \mathrm{mg}$ of each functionalized CHNC were placed into a cylindrical holder and pressed using a hydraulic press to obtain uniform discs (13 $\mathrm{mm}$ in diameter and $0.4 \mathrm{~mm}$ in thickness). The test was done in triplicate.

\subsection{Barrier Properties}

Water vapor transmission tests of the materials (thickness range from 0.06 to $0.10 \pm 0.01 \mathrm{~mm}$ ) were performed at $30.0 \pm 0.2{ }^{\circ} \mathrm{C}$ on a gravimetric cell in which a small amount of liquid water $(2 \mathrm{~mL})$ was sealed by a membrane. The cell was put on an analytical balance $\left( \pm 10^{-5} \mathrm{~g}\right)$, and the weight loss of the cell, only due to the permeation of the water vapor through the membrane, was followed by a computer connected to the balance. Water activity inside the cell was 1 , whereas the downstream average humidity was $33 \pm 2 \%$ as recorded with a thermohygrometer. Changes in the weight of the cell were recorded as a function of time. The water vapor transmission rate (WVTR) was determined from the following Equation (2):

$$
\operatorname{WVTR}\left(\frac{\mathrm{g} \cdot \mathrm{mm}}{\mathrm{m}^{2} \cdot \text { day }}\right)=\frac{\mathrm{m} \cdot \ell}{\mathrm{A}(1-\mathrm{a})}
$$

where WVTR is the water vapor flow passing through the films per unit time; " $\ell$ " is the thickness of the films; " $\mathrm{A}$ " is the area of the films $\left(2.54 \mathrm{~cm}^{2}\right)$ exposed to the water vapor flow; and "a" is the relative humidity in the thermostatic system. For each film, WVP measurements were performed at least three times.

\subsection{Antifungal Activity against Aspergillus Niger}

In order to evaluate the anti-fungal activity of the composite films against a common rot of food and indoor environments, the mold fungus Aspergillus niger (CBS 554.65) was cultured and incubated aerobically for $72 \mathrm{~h}$ at $25^{\circ} \mathrm{C}$ in Petri dishes with solid substrate of Malte Extract Agar (MEA, Sharlab). After growing, an aliquot of spores was diluted in Ringer solution $(14 \mathrm{~mL})$ and was aseptically inoculated on the MEA surfaces by spray method (with $40 \mu \mathrm{L}$ of dissolution at $1.21 \times 106$ Spores $\mathrm{mL}^{-1}$ ).

Finally, $1 \mathrm{~cm} \times 1 \mathrm{~cm}$ shaped samples (with an average thickness of $0.08 \mathrm{~mm}$ ) of each nanocomposite films and PLA films (the latter was used as control) were introduced into the MEA plates to assess the fungal inhibition. Each sample was prepared in triplicate.

After 7 days of incubation at $25 \pm 1.5^{\circ} \mathrm{C}$, the films were gently extracted from the agar and washed with Ringer solution $(1 \mathrm{~mL})$ to obtain a spore solution. Then samples were vortexed and stained with LPCB taking $20 \mu \mathrm{L}$ of each sample to count spores concentration with an automated cell counter (Cellometer ${ }^{\circledR}$ Mini Nexcelom Bioscience LLC, Lawrence, MA, USA). The fungal growth inhibition (FGI) was calculated as concentration of spores (conidia) per milliliter, according to the Equation (3):

$$
F G I(\%)=\frac{C_{g}-T_{g}}{C_{g}} \times 100
$$

where $C_{g}$ is the average concentration in the control samples set (PLA films and fungal dish) and $T_{g}$ is the average concentration in the treated set (film tested), both expressed as concentration of spores (conidia) per milliliter [18].

\subsection{Thermal Stability and Mechanical Properties}

Thermogravimetric analysis (TGA) assays were carried out in a TGA/SDTA 851 Mettler Toledo instrument. All samples $(\sim 8 \mathrm{mg})$ were heated at a constant rate of $10^{\circ} \mathrm{C} \mathrm{min}^{-1}$ from 25 to $900{ }^{\circ} \mathrm{C}$ under a nitrogen atmosphere of $20 \mathrm{~mL} \mathrm{~min}^{-1}$. 
Tensile tests were conducted under ambient conditions using a Material Testing Systems (MTS Insight 10) device using a load cell of $250 \mathrm{~N}$ and a deformation rate of $3 \mathrm{~mm} \mathrm{~min}^{-1}$. Ten replicates of each sample (rectangular-shape specimens of $6 \times 1 \mathrm{~cm}^{2}$ and gauge length of $2 \mathrm{~cm}$ ) were used to determine the average values of Young's modulus, tensile strength and elongation at break using MTS TestWorks 4 software (Version 4.09A, MTS System Corporation, Eden Prairie, MN, USA).

\section{Results and Discussion}

\subsection{General Characterization of Chitin Derivatives: $\mathrm{C}_{2} \mathrm{CHNC}$ and $\mathrm{C}_{12} \mathrm{CHNC}$}

The preparation of PLA-based nanocomposite films with chitin nanocrystals as reinforcing nanofiller requires chemical modification of the nanofillers' surface. Two sets of functionalized chitin nanocrystals $\left(\mathrm{C}_{2} \mathrm{CHNC}\right.$ and $\mathrm{C}_{12} \mathrm{CHNC}$, Figure 1$)$ were prepared using heterogeneous conditions to increase the hydrophobic surface character, and thus improve the dispersability into the PLA matrix.

Figure 2a displays ATR-FTIR spectrum of $\mathrm{CHNC}$ and its derivatives, i.e., $\mathrm{C}_{2} \mathrm{CHNC}$ (modified with anhydride acetic) and $\mathrm{C}_{12} \mathrm{CHNC}$ (modified with fatty acid). The success of the modifications was clearly confirmed, mainly based on the emergence of a new band at around $1735 \mathrm{~cm}^{-1}$, assigned to the carbonyl ester group stretching mode $(\mathrm{C}=\mathrm{O}$, Figure $2 \mathrm{a})$ display in the $\mathrm{C}_{2} \mathrm{CHNC}$ and $\mathrm{C}_{12} \mathrm{CHNC}$ spectra [41,45-47]. This peak is smaller in the case of the nanocomposite films prepared with $\mathrm{C}_{12} \mathrm{CHNC}$, possibly due to a smaller extent of the surface substitution. An increase in the intensity of the $\mathrm{C}-\mathrm{H}$ band in the range $2860-2900 \mathrm{~cm}^{-1}$ arising from the aliphatic acid chain was also observed in the case of $\mathrm{C}_{12} \mathrm{CHNC}$ sample $[48,49]$. In all spectra the characteristic absorption bands of $\alpha$-chitin i.e., at $1555 \mathrm{~cm}^{-1}$ ascribed to NH bending (amide II), at 1619 and $1655 \mathrm{~cm}^{-1}$ corresponding to carbonyl stretching bands (amide I) and at 3200 and $3400 \mathrm{~cm}^{-1}$ of N-H and O-H stretching band, respectively [50,51] are present. Nonetheless, a decrease in intensity of the broad band at about $3400 \mathrm{~cm}^{-1}$, in particular for $\mathrm{C}_{2} \mathrm{CHNC}$ sample, was observed indicating the substitution of hydroxyl groups by acetyl groups. This decrease and no disappearance of $\mathrm{O}-\mathrm{H}$ stretching bands on the functionalized samples suggests that: (1) the modification has taken place on the surface of the chitin nanocrystals remaining intact inside hydroxyl group; and (2) an incomplete substitution of all of the surface $\mathrm{OH}$ groups $[47,52]$.

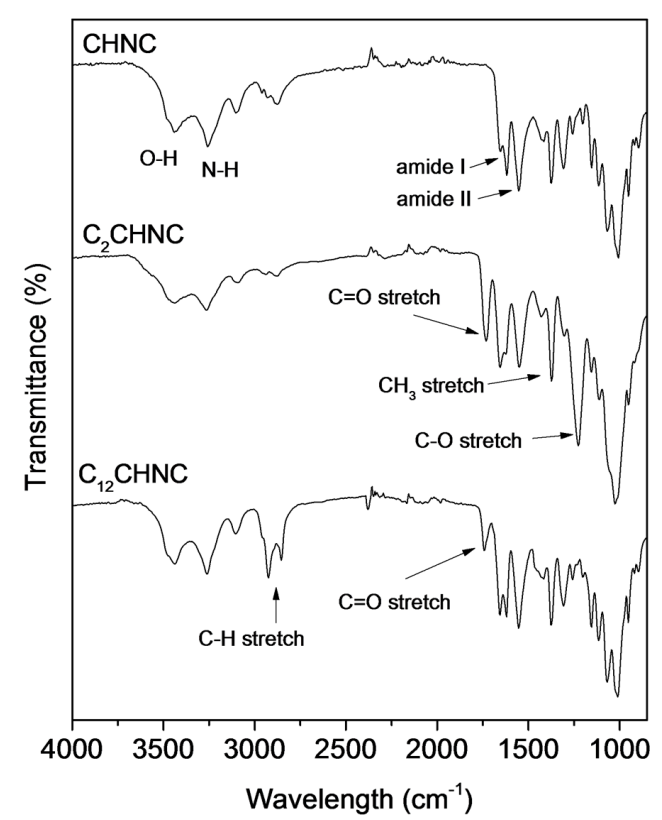

(a)

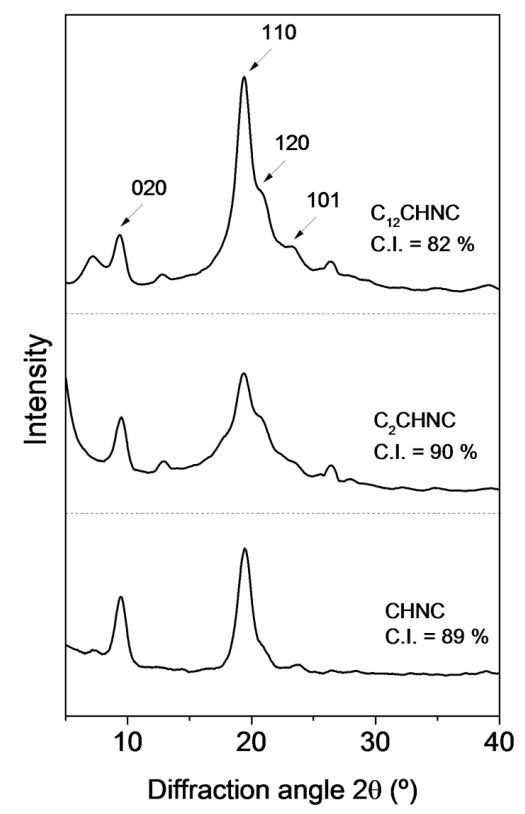

(b)

Figure 2. (a) ATR-FTIR spectra; and (b) X-ray diffraction of CHNC and acylated chitin nanocrystals $\left(\mathrm{C}_{2} \mathrm{CHNC}\right.$ and $\left.\mathrm{C}_{12} \mathrm{CHNC}\right)$. 
The crystal structure of $\mathrm{CHNC}$ and its derivatives was analyzed by X-ray diffraction (Figure 2b). The four typical crystalline reflections of $\alpha$-chitin at $9.5^{\circ}, 19.5^{\circ}, 21.0^{\circ}$ and $23.5^{\circ}$ indexed as $020,110,120$ and 101 crystallographic planes, with a basal spacing of $9.31,4.55,4.25$ and $3.80 \AA$, respectively, were observed $[43,53,54]$. The stronger reflections were clearly observed at $9.5^{\circ}$ and $21.0^{\circ}$ and the lower reflections at higher $2 \theta$ values. CHNC presented a crystallinity index of $89 \%$. The crystalline structure of the functionalized chitin nanocrystals remained the same as $\mathrm{CHNC}$ and the C.I. were found to be $90 \%$ and $82 \%$ for $\mathrm{C}_{2} \mathrm{CHNC}$ and $\mathrm{C}_{12} \mathrm{CHNC}$, respectively. The decrease of the crystallinity of $\mathrm{C}_{12} \mathrm{CHNC}$ is mainly due to the destruction of the crystalline regions of the nanocrystals, which led to a reduction of nanoparticle length (confirmed by AFM, see below). The fact that, modified chitin nanocrystals showed the same diffraction pattern than unmodified chitin, suggest that the modification took place at the surface of the nanocrystals and on the more accessible amorphous domains.

This data corroborate with the sizes of CHNC and functionalized chitin nanocrystals that were roughly estimated using AFM imaging (Figure 3) and were found to be approximately 300, 290 and $185 \mathrm{~nm}$ in length (L) for $\mathrm{CHNC}, \mathrm{C}_{2} \mathrm{CHNC}$ and $\mathrm{C}_{12} \mathrm{CHNC}$, respectively. Actually, after the heterogeneous surface modification, the ensuing $\mathrm{C}_{12} \mathrm{CHNC}$ showed an important decrease of their length, justified by the partial detachment of the modified fibrils from the crystalline structure [55]. No significant changes were observed in the width (Ø) of the samples after the reactions. The typical rod-like morphology of the samples remained after the chemical modification.
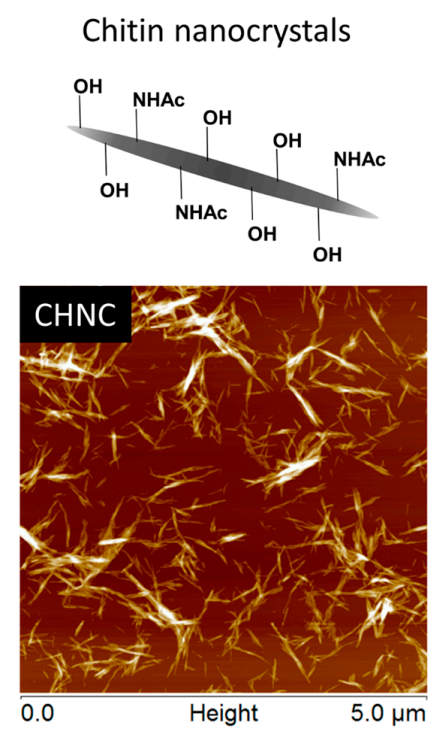

$\mathrm{L} \sim 300 \mathrm{~nm} ; \varnothing \sim 60 \mathrm{~nm}$

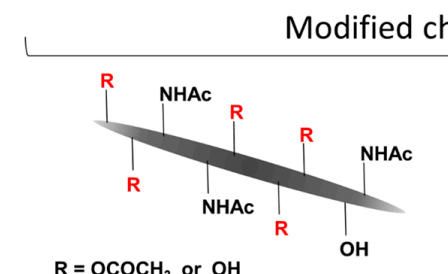

$\mathrm{L} \sim 290 \mathrm{~nm} ; \varnothing \sim 50 \mathrm{~nm}$
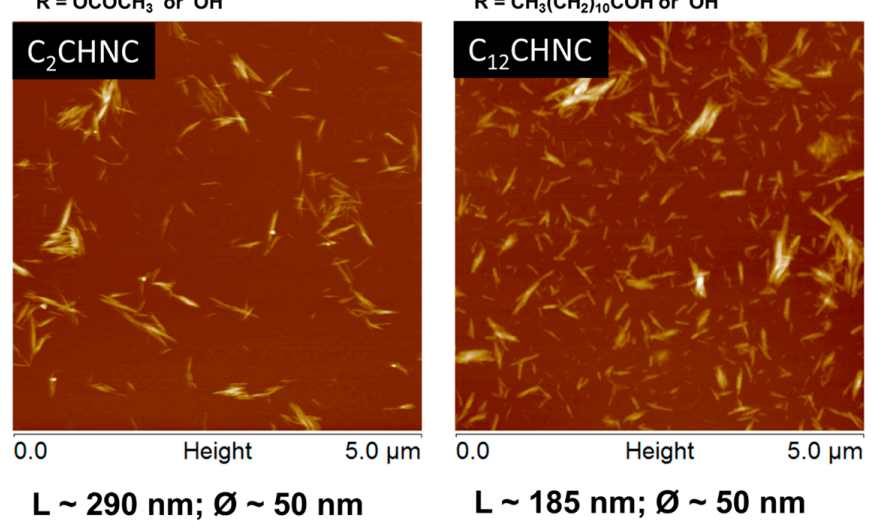

Figure 3. AFM height images of $\mathrm{CHNC}, \mathrm{C}_{2} \mathrm{CHNC}$ and $\mathrm{C}_{12} \mathrm{CHNC}$ (L, length; and $\varnothing$, width).

The results have demonstrated that the modification was essentially limited to the nanocrystals' surface or to the more accessible amorphous chitin domains, not affecting significantly the crystalline regions of the inner layers in the nanocrystals.

The thermal behavior of the CHNC before and after the reactions was evaluated by thermogravimetric analysis (Figure 4 and Table 2). Derivative TGA (dTGA) tracing of CHNC showed one weight-loss-step with a maximum degradation step at $387^{\circ} \mathrm{C}$ associated with the degradation of chitin molecules. The thermal degradation profile of $\mathrm{C}_{2} \mathrm{CHNC}$ showed to be less stable, since they started to decompose at lower temperatures. Derivative TGA curves of $\mathrm{C}_{2} \mathrm{CHNC}$ displayed two degradation steps: the first is a wide degradation that started at around 180 until $310^{\circ} \mathrm{C}$; and the second step occurs at $364^{\circ} \mathrm{C}$. These thermal decomposition behaviors derived from chitin diacetate and chitin [45]. This slight decrease in thermal stability of CHNC is commonly found in surface-acetylated chitin. The derivative TGA curve of $\mathrm{C}_{12} \mathrm{CHNC}$ displayed two separate degradation steps at $322^{\circ} \mathrm{C}$ 
and $390^{\circ} \mathrm{C}$ associated to the degradation of esterified chitin fraction and unmodified chitin fraction, respectively. Interestingly, a decrease of water content in the $\mathrm{C}_{12} \mathrm{CHNC}$ samples was observed, suggesting that the modification of $\mathrm{CHNC}$ made them more hydrophobic $[56,57]$.
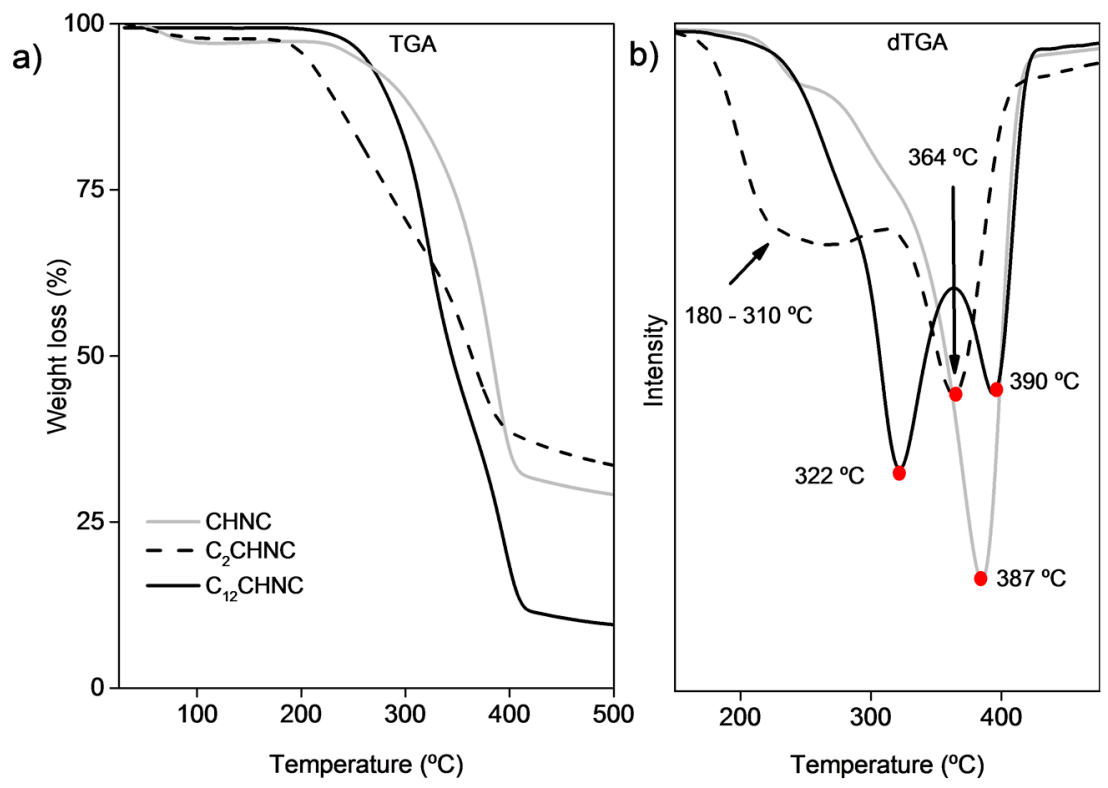

Figure 4. TGA (a); and dTGA (b) profiles of $\mathrm{CHNC}, \mathrm{C}_{2} \mathrm{CHNC}$ and $\mathrm{C}_{12} \mathrm{CHNC}$.

Table 2. Degradation temperatures of $\mathrm{CHNC}, \mathrm{C}_{2} \mathrm{CHNC}, \mathrm{C}_{12} \mathrm{CHNC}$ and PLA-based nanocomposites.

\begin{tabular}{ccc}
\hline Sample & Temp. Main Degradation $\left({ }^{\circ} \mathrm{C}\right)$ & Temp. Second Degradation $\left({ }^{\circ} \mathbf{C}\right)$ \\
\hline CHNC & 387.1 & \\
$\mathrm{C}_{2}$ CHNC & 364.3 & $380-310$ \\
$\mathrm{C}_{12}$ CHNC & 390.2 & \\
PLA & 364.3 & \\
PLA $/ C_{2} 0.5$ & 362.3 & \\
PLA $/ C_{2} 1$ & 364.4 & \\
PLA $/ C_{2} 2$ & 363.5 & \\
PLA $/ C_{12} 0.5$ & 363.3 & \\
PLA $/ C_{12} 1$ & 360.2 & \\
PLA $/ C_{12} 2$ & 358.0 & \\
\hline
\end{tabular}

Figure 5 displays the profile obtained for the dynamic water contact angle measurements placed on the surface of the CHNC pellets, before and after the surface chemical modifications with acetic anhydride and dodecanoyl chloride acid. Whereas the unmodified CHNC showed the typical high water affinity associated with a fast decrease in the initially low contact angle $\left(55^{\circ}\right)[58,59]$, modified $\mathrm{C}_{2} \mathrm{CHNC}$ and $\mathrm{C}_{12} \mathrm{CHNC}$ samples showed a higher $\left(68.5^{\circ}\right.$ and $95.6^{\circ}$, respectively ) and constant contact angle [47]. The drop contact angle remained constant during the time (Figure 5) as a result of the hydroxyl groups' replacement by hydrophobic chains (acetyl groups and dodecanoyl chains) on the surface of acylated chitin nanocrystals. As expected, $\mathrm{C}_{12} \mathrm{CHNC}$ displayed the larger value of contact angle $\left(95.6^{\circ}\right)$ due to its long aliphatic chain. The surface energy components (polar $\gamma_{\mathrm{sp}}$, dispersive $\gamma_{\mathrm{sd}}$ and total $\gamma_{\mathrm{s}}$ ) of $\mathrm{C}_{12} \mathrm{CHNC}$ samples were determined and are listed in Table 3 . The decrease in the polar component $\left(\gamma_{\mathrm{sp}}\right)$ values from $16.3(\mathrm{CHNC})$ to $0.7 \mathrm{~mJ} \mathrm{~m}^{-2}\left(\mathrm{C}_{12} \mathrm{CHNC}\right)$ confirmed the chemical modification on the CHNC surface. 


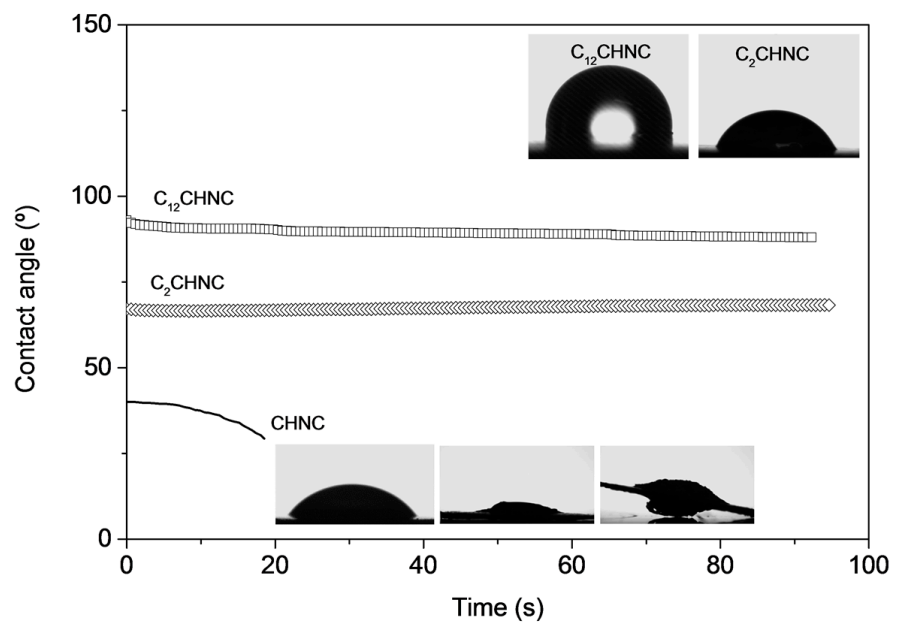

Figure 5. Dynamic water contact angle of $\mathrm{CHNC}$ and functionalized $\mathrm{C}_{2} \mathrm{CHNC}$ and $\mathrm{C}_{12} \mathrm{CHNC}$ and image of the water drop on the surface of the respective pellet.

\subsection{Characterization of PLA-Based Nanocomposites (PLA/C $C_{2} \mathrm{CHNC}$ and $P L A / \mathrm{C}_{12} \mathrm{CHNC}$ )}

\subsubsection{Optical Properties of the Nanocomposites}

One of the important parameters in packaging is the transparency, thus the light transmittance of the films was measured from 700 to $400 \mathrm{~nm}$ (Figure 6). As listed in Figure 6b, the addition of nanofillers in the matrix affected the transmittance of the final nanocomposites, decreasing its values gradually with the increment of chitin nanocrystals in the matrix. However, the materials are still translucent, as shown in Figure 6a. The transmittance (measured for specimens with a thickness of approximately $0.07 \mathrm{~mm}$ ) at $600 \mathrm{~nm}$ was about $72 \%$ for PLA, $66 \%$ for PLA $/ \mathrm{C}_{2} 0.5$ and $67 \%$ for the PLA $/ C_{12} 0.5$ nanocomposites (Figure $6 \mathrm{~b}$ ). These results indicate that the transmittance is not affected by the kind of modified CHNC.

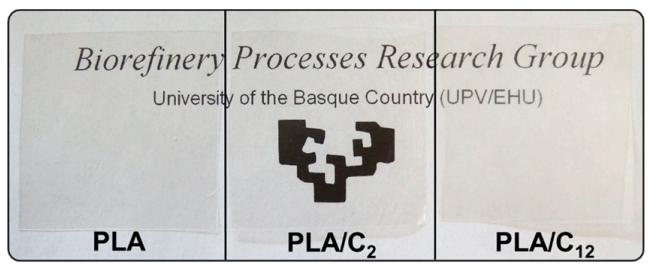

(a)

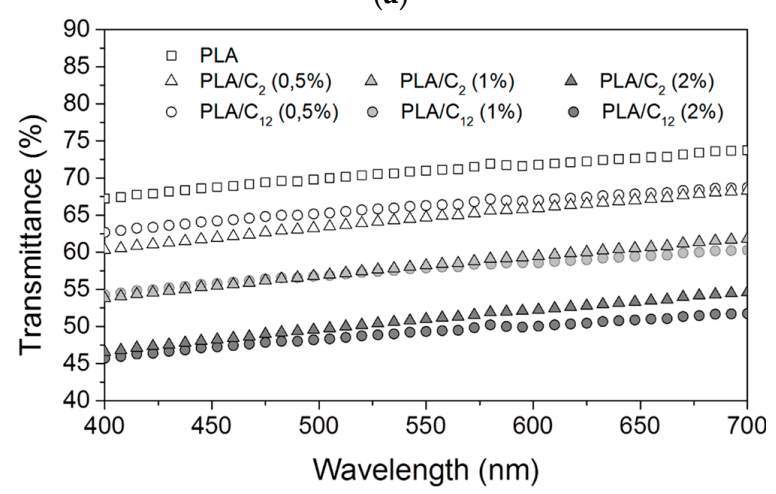

(b)

Figure 6. Photographs of PLA, PLA/ $\mathrm{C}_{2} 0.5$ and PLA/ $\mathrm{C}_{12} 0.5$ nanocomposite films (a); and transmittance traces of PLA film and PLA $/ C_{2}$ and PLA/ $C_{12}$ nanocomposite films (b). 


\subsubsection{Thermal and Mechanical Properties}

Like for the modified CHNC, the thermal stability and degradation profiles of the PLA nanocomposite materials were assessed by thermogravimetry (Table 1). The TGA profile of the PLA film exhibits a typical single weight-loss step, with a maximum decomposition rate at $364^{\circ} \mathrm{C}$. The thermal decomposition process of all the PLA $/ \mathrm{C}_{2} \mathrm{CHNC}$ (Figure 7a) and PLA $/ \mathrm{C}_{12} \mathrm{CHNC}$ (Figure $7 \mathrm{~b}$ ) nanocomposites also presented a single weight loss step profile. The thermal stability profiles of all samples were very similar without important changes, contrarily with Guan et al. work [15] where the thermal degradation of PLA bionanocomposites with $2 \%$ of chitin nanocrystals decreased about $25^{\circ} \mathrm{C}$.
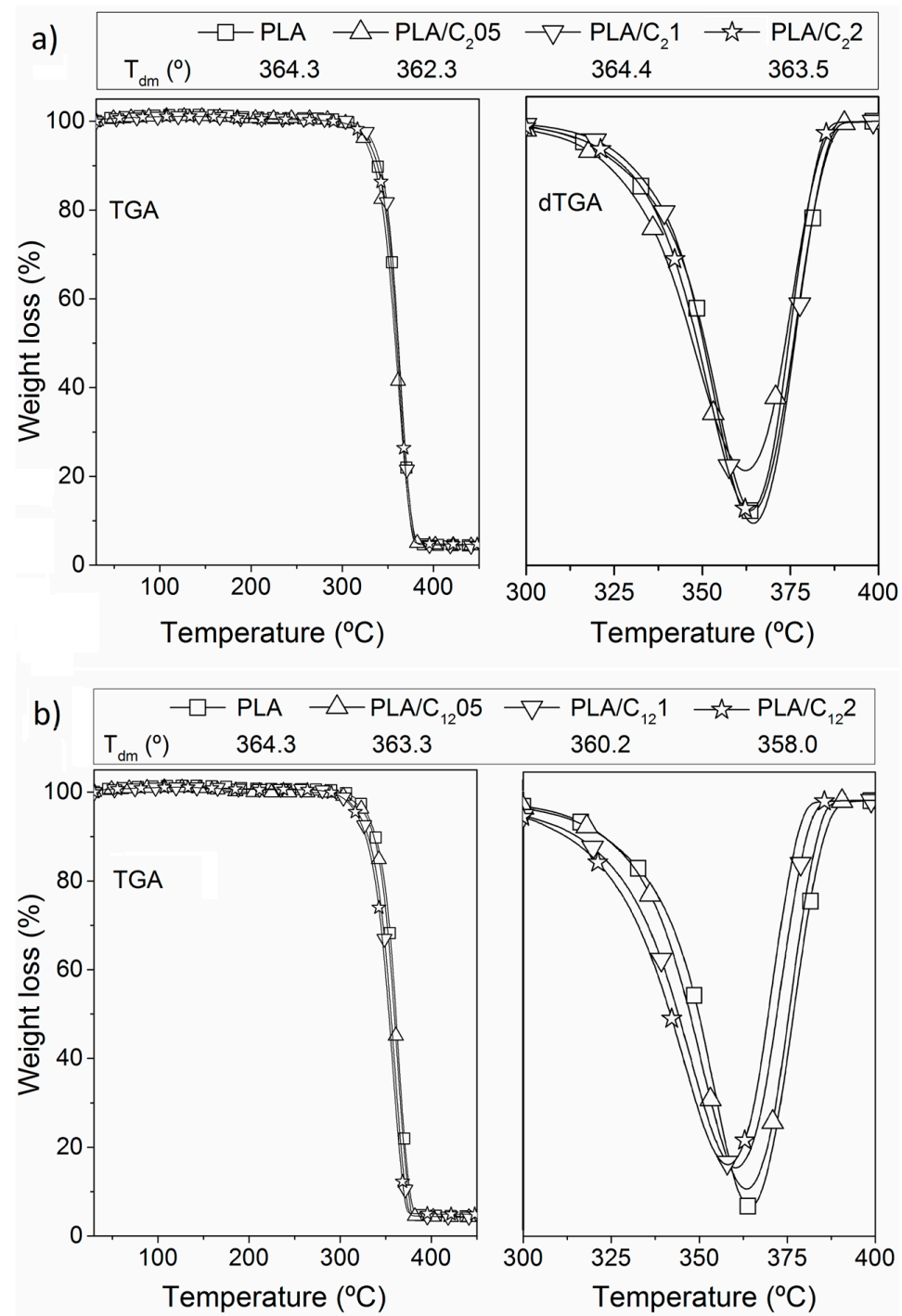

Figure 7. Themogravimetric analysis of: PLA/ $C_{2}$ nanocomposite (a); and PLA/ $C_{12}$ nanocomposite (b).

The mechanical properties of PLA films and nanocomposite films were evaluated in terms of Young's modulus, tensile strength and elongation at break (Figure 8). The unfilled PLA films showed characteristic values in Young's modulus at around $2 \mathrm{GPa}$, in tensile strength of $44 \mathrm{MPa}$ and elongation at break of $3.1 \%[60,61]$. Contrary to previous works $[20,62,63]$ related to the incorporation of CHNC into PLA matrices, in the present work, a minor loss in modulus and tensile strength was observed when the modified CHNC were incorporated in the PLA matrices. This effect was associated to the $\mathrm{C}_{2} \mathrm{CHNC}$ and $\mathrm{C}_{12} \mathrm{CHNC}$ aggregation. However, PLA-based nanocomposites prepared with other type of nanofillers (i.e., nanocrystalline cellulose, and nanoclays) also showed no significant effect on the 
mechanical properties of the final materials [14]. Regarding elongation at break, characteristic decrease of this parameter was observed in all materials due to the incorporation of crystal nanofillers.

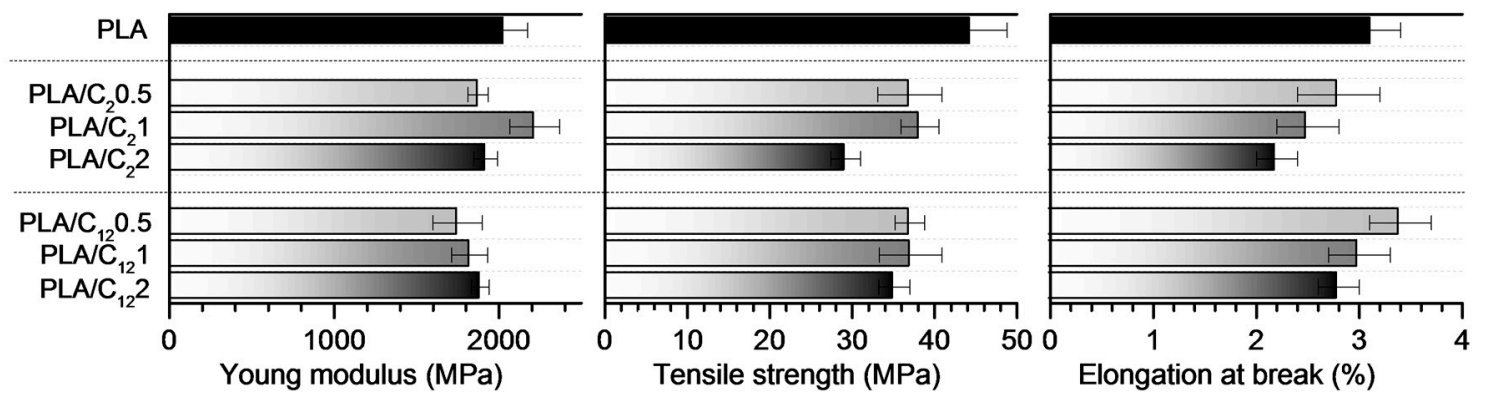

Figure 8. Mechanical properties of PLA films and PLA nanocomposites in terms of Young's modulus, tensile strength and elongation at break.

\subsubsection{Contact Angles and Surface Energy of the PLA-Based Nanocomposites}

The contact angle values of PLA nanocomposites are summarized in Table 3. Regarding the contact angles of the PLA $/ \mathrm{C}_{2}$ nanocomposites, the data were similar to those of PLA film. However, the enhancement in the hydrophobic character of the $\mathrm{C}_{12} \mathrm{CHNC}$ after esterification was clearly demonstrated by the superior water contact angle from 89 to $96^{\circ}$ for the PLA/ $C_{12}$ nanocomposites compared with $81^{\circ}$ for the PLA films. The surface energy of the PLA/ $C_{12}$ nanocomposites were calculated using other liquids besides water with different polarities-diiodomethane and ethylenglycol (Table 3).

The surface energy of PLA $/ C_{12}\left(32 \mathrm{~mJ} / \mathrm{m}^{2}\right)$ was lightly superior to PLA film $\left(27 \mathrm{~mJ} / \mathrm{m}^{2}\right)$ because of the high values of the dispersive component surface energy of the modified CHNC. No significant differences on the surface energy were found regarding the amount of modified chitin in the PLA nanocomposites.

Table 3. Contact angle and surface energy components (polar $\gamma_{\mathrm{sp}}$, dispersive $\gamma_{\mathrm{sd}}$ and total $\gamma_{\mathrm{s}}$ ) values of the samples.

\begin{tabular}{|c|c|c|c|c|c|c|}
\hline \multirow{2}{*}{ Samples } & \multicolumn{3}{|c|}{ Contact Angles $\left({ }^{\circ}\right)$} & $\left(\gamma_{\mathrm{sp}}\right)$ & $\left(\gamma_{s d}\right)$ & $\left(\gamma_{s}\right)$ \\
\hline & Water & Diiodomethane & Ethylene Glycol & & $\left(\mathrm{mJ} / \mathrm{m}^{2}\right)$ & \\
\hline CHNC & $55.0 \pm 2.0$ & $45.5 \pm 1.0$ & $26.6 \pm 0.8$ & $16.3 \pm 1.1$ & $33.4 \pm 0.4$ & $49.7 \pm 1.6$ \\
\hline $\mathrm{C}_{12} \mathrm{CHNC}$ & $95.6 \pm 1.9$ & $53.3 \pm 1.5$ & $81.4 \pm 2.1$ & $0.7 \pm 0.2$ & $28.0 \pm 0.5$ & $28.7 \pm 0.7$ \\
\hline PLA & $81.3 \pm 1.9$ & $82.5 \pm 1.3$ & $58.8 \pm 1.8$ & $10.5 \pm 1.0$ & $16.5 \pm 0.3$ & $27.0 \pm 1.4$ \\
\hline PLA $/ C_{12} 0.5$ & $88.8 \pm 0.9$ & $53.7 \pm 2.1$ & $65.2 \pm 2.5$ & $2.2 \pm 0.2$ & $30.2 \pm 0.2$ & $32.4 \pm 0.5$ \\
\hline $\mathrm{PLA} / \mathrm{C}_{12} 1$ & $89.1 \pm 2.1$ & $53.6 \pm 1.2$ & $66.4 \pm 1.9$ & $2.1 \pm 0.5$ & $30.1 \pm 0.5$ & $32.2 \pm 1.1$ \\
\hline $\mathrm{PLA} / \mathrm{C}_{12} 2$ & $95.6 \pm 1.1$ & $53.5 \pm 0.8$ & $69.0 \pm 1.1$ & $0.8 \pm 0.1$ & $31.1 \pm 0.3$ & $31.8 \pm 0.4$ \\
\hline
\end{tabular}

\subsubsection{Barrier Properties: Water Vapor Transmission Tests}

The water vapor transmission rate (WVTR) of PLA-based nanocomposites was analyzed because of the potential use of these materials in food packaging. The assessment of this parameter is important because of the role of water in microbial development and deteriorative effects. In general, the data listed in Figure 9 demonstrate a slight decrease in the WVTR, which is directly associated with the incorporation of hydrophobic groups on the surface of the CHNC. The range of values is in accordance with those found in previous works [43]. As expected, the decrease in the WVTR is more evident for the PLA-based nanocomposites prepared with the CHNC modified with fatty aliphatic chains. The amount $(0.5 \%, 1 \%$ and $2 \%)$ of both sets of CHNC did not significantly affect the WVTR. These results are consistent with the water contact angles measurements. 


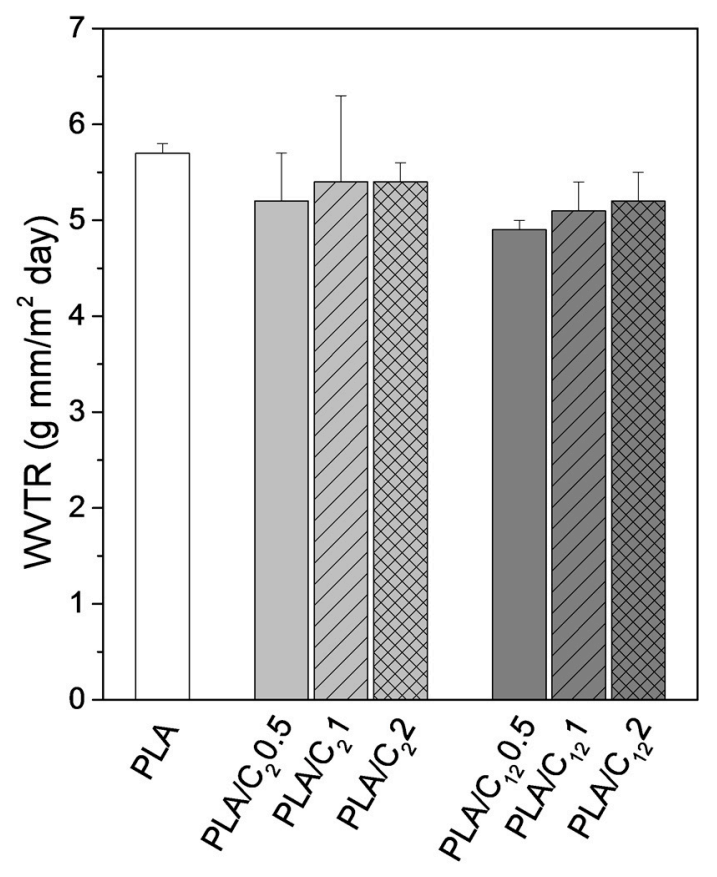

Figure 9. WVTR of PLA films and PLA nanocomposites.

\subsubsection{Study of the Fungal Inhibition}

The main purpose of fungal inhibition study towards A. niger was to analyze the potential use of PLA-chitin based nanocomposites films for active food packaging applications, since it is a determinant factor for this industry. The study was performed using $A$. niger since it is known as a widespread contaminant of food namely fruits and vegetables. Moreover, some of $A$. niger strains has been linked to a wide array of human health problems [64].

The antifungal and antimicrobial effect of chitin and chitin nanofillers has been previously reported [34,65-67]. Figure 10 shows the number of colony forming units per milliliter and the fungal growth inhibition (FGI, \%) for the antifungal activity of the PLA film (reference) and the PLA-based nanocomposite films after seven days of $A$. niger incubation at $25^{\circ} \mathrm{C}$. The data showed that the incorporation of modified CHNC considerably decreased the fungal activity of all materials. Nevertheless, the two sets of nanocomposite films presented distinguish behaviors: (1) PLA $/ C_{2}$ films showed a constant fungal growth inhibition of approximately $50 \%$ independently of the $\mathrm{C}_{2} \mathrm{CHNC}$ concentration; and (2) the PLA $/ \mathrm{C}_{12}$ materials presented an increase of the fungal growth inhibition from $48 \%$ to $61 \%$ with the incorporation of $\mathrm{C}_{12} \mathrm{CHNC}$ with respect to the reference material (PLA film).

These results are in agreement with the results reported earlier concerning the incorporation of chitin nanocrystals and/or nanofibers in other polymeric matrices [36,37,65-67]. 


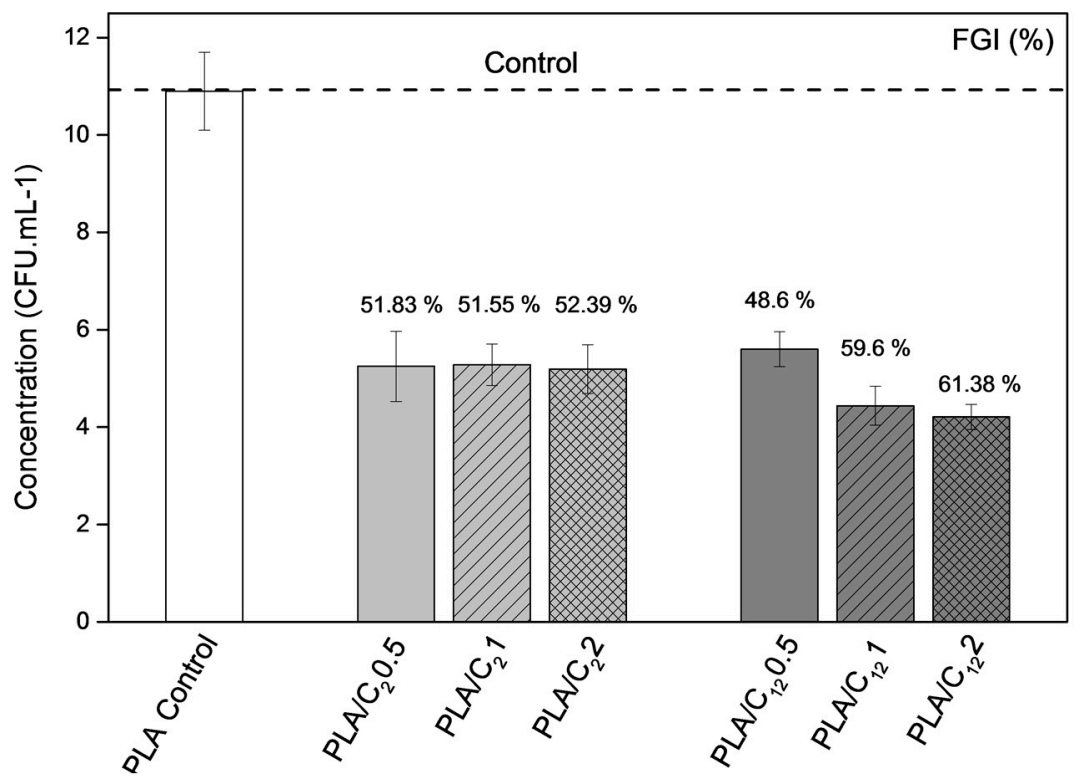

Figure 10. Antifungal activity against $A$. niger of PLA film (control sample), PLA/ $C_{2}$ and PLA/C 12 bionanocomposite films. The value on the top of each bar corresponds to the fungal growth inhibition (FGI, \%). Error bar corresponds to standard deviation (SD, $n=4)$.

\section{Conclusions}

Chitin nanocrystals were successfully modified via acylation using anhydride acetic and dodecanoyl chloride acid. Poly(lactic acid)-based nanocomposite films were prepared by extrusion/compression approach using different concentrations of both sets of modified CHNC followed by their evaluation for packaging applications. The data demonstrated that both sets of modified CHNC act as functional agents, i.e., they slightly enhanced the hydrophobic character of the materials and improved the antifungal activity. The different $\mathrm{CHNC}$ amounts incorporated in the PLA matrix have no detrimental effect on the mechanical properties in tension and light transmittance, compared to neat PLA. It was also found that the nanocomposite films prepared with the CHNC modified with dodecanoyl chloride acid presented better properties to act as active food packaging.

Acknowledgments: The authors are thankful for the financial support from the European Commission through the European Project ECLIPSE (NMP-280786); the Department of Education of the Basque Government through project IT1008-16; and scholarship of young researchers training and project. The authors also acknowledge the technical and human support of General Research Services (SGIker) from the UPV/EHU for water vapor transmission and oxygen transmission analyses.

Author Contributions: A.M.S., S.C.M.F. and J.L. conceived and designed the experiments; A.M.S. performed the experiments and R.H.D. executed the antifungal tests; A.M.S., R.H.D., M.A.A., S.C.M.F. and J.L. analyzed the data and wrote the paper.

Conflicts of Interest: The authors declare no conflict of interest.

\section{References}

1. Byun, Y.; Kim, Y.T. Bioplastics for food packaging: Chemistry and physics. In Innovations in Food Packaging; Elsevier: Amsterdam, The Nederlands, 2014; pp. 353-368. ISBN: 978-0-12-394601-0.

2. Rhim, J.-W.; Park, H.-M.; Ha, C.-S. Bio-nanocomposites for food packaging applications. Prog. Polym. Sci. 2013, 38, 1629-1652. [CrossRef]

3. Siracusa, V. Food Packaging Permeability Behaviour: A Report. Int. J. Polym. Sci. 2012, 2012, 1-11. [CrossRef]

4. Auras, R.; Harte, B.; Selke, S. An overview of polylactides as packaging materials. Macromol. Biosci. 2004, 4, 835-864. [CrossRef] [PubMed] 
5. Ikada, Y.; Tsuji, H. Biodegradable polyesters for medical and ecological applications. Macromol. Rapid Commun. 2000, 21, 117-132. [CrossRef]

6. Arrieta, M.P.; López, J.; Ferrándiz, S.; Peltzer, M.A. Characterization of PLA-limonene blends for food packaging applications. Polym. Test. 2013, 32, 760-768. [CrossRef]

7. Fortunati, E.; Armentano, I.; Iannoni, A.; Kenny, J.M. Development and thermal behaviour of ternary PLA matrix composites. Polym. Degrad. Stab. 2010, 95, 2200-2206. [CrossRef]

8. Bengtsson, M.; Baillif, M. Le; Oksman, K. Extrusion and mechanical properties of highly filled cellulose fibre-polypropylene composites. Compos. Part A Appl. Sci. Manuf. 2007, 38, 1922-1931. [CrossRef]

9. Peniche, C.; Argüellers-Monal, W.; Goycoolea, F. Chitin and Chitosan: Major Sources, Properties and Applications. In Monomers, Polymers and Composites from Renewable Resources; Belgacem, M.N., Gandini, A., Eds.; Elsevier: Amsterdam, The Nederlands, 2008; Volume 1, pp. 517-542. ISBN: 978-0-08-045316-3.

10. Babu, R.P.; O'Connor, K.; Seeram, R. Current progress on bio-based polymers and their future trends. Prog. Biomater. 2013, 2, 8. [CrossRef]

11. Vasita, R.; Katti, D.S. Nanofibers and their applications in tissue engineering. Int. J. Nanomed. 2006, 1, 15-30. [CrossRef] [PubMed]

12. Spinella, S.; Lo Re, G.; Liu, B.; Dorgan, J.; Habibi, Y.; Leclère, P.; Raquez, J.-M.; Dubois, P.; Gross, R.A. Polylactide/cellulose nanocrystal nanocomposites: Efficient routes for nanofiber modification and effects of nanofiber chemistry on PLA reinforcement. Polymer 2015, 65, 9-17. [CrossRef]

13. Lo Re, G.; Benali, S.; Habibi, Y.; Raquez, J.-M.; Dubois, P. Stereocomplexed PLA nanocomposites: From in situ polymerization to materials properties. Eur. Polym. J. 2014, 54, 138-150. [CrossRef]

14. Trifol, J.; Plackett, D.; Sillard, C.; Hassager, O.; Daugaard, A.E.; Bras, J.; Szabo, P. A comparison of partially acetylated nanocellulose, nanocrystalline cellulose, and nanoclay as fillers for high-performance polylactide nanocomposites. J. Appl. Polym. Sci. 2016, 133, 43257. [CrossRef]

15. Trifol, J.; Plackett, D.; Sillard, C.; Szabo, P.; Bras, J.; Daugaard, A.E. Hybrid poly(lactic acid)/nanocellulose/nanoclay composites with synergistically enhanced barrier properties and improved thermomechanical resistance. Polym. Int. 2016, 65, 988-995. [CrossRef]

16. Missoum, K.; Bras, J.; Belgacem, M.N. Organization of aliphatic chains grafted on nanofibrillated cellulose and influence on final properties. Cellulose 2012, 19, 1957-1973. [CrossRef]

17. Ifuku, S.; Ikuta, A.; Egusa, M.; Kaminaka, H.; Izawa, H.; Morimoto, M.; Saimoto, H. Preparation of high-strength transparent chitosan film reinforced with surface-deacetylated chitin nanofibers. Carbohydr. Polym. 2013, 98, 1198-1202. [CrossRef] [PubMed]

18. Salaberria, A.M.; Diaz, R.H.; Labidi, J.; Fernandes, S.M. Role of chitin nanocrystals and nanofibers on physical, mechanical and functional properties in thermoplastic starch films. Food Hydrocoll. 2015, 46, 93-102. [CrossRef]

19. Lopez, O.; Garcia, M.A.; Villar, M.A.; Gentili, A.; Rodriguez, M.S.; Albertengo, L. Thermo-compression of biodegradable thermoplastic corn starch films containing chitin and chitosan. LWT Food Sci. Technol. 2014, 57, 106-115. [CrossRef]

20. Salaberria, A.M.; Labidi, J.; Fernandes, S.C.M. Different routes to turn chitin into stunning nano-objects. Eur. Polym. J. 2015, 68, 503-515. [CrossRef]

21. Salaberria, A.M.; Labidi, J.; Fernandes, S.C.M. Chitin nanocrystals and nanofibers as nano-sized fillers into thermoplastic starch-based biocomposites processed by melt-mixing. Chem. Eng. J. 2014, 256, 356-364. [CrossRef]

22. Salaberria, A.M.; Fernandes, S.C.M.; Diaz, R.H.; Labidi, J. Processing of $\alpha$-chitin nanofibers by dynamic high pressure homogenization: Characterization and antifungal activity against A. Niger. Carbohydr. Polym. 2015, 116, 286-291. [CrossRef] [PubMed]

23. Salaberria, A.M.; Diaz, R.H.; Labidi, J.; Fernandes, S.C.M. Preparing valuable renewable nanocomposite films based exclusively on oceanic biomass-Chitin nanofillers and chitosan. React. Funct. Polym. 2015, 89, 31-39. [CrossRef]

24. Paillet, M.; Dufresne, A. Chitin whisker reinforced thermoplastic nanocomposites. Macromolecules 2001, 34, 6527-6530. [CrossRef]

25. Guan, Q.; Naguib, H.E. Fabrication and characterization of PLA/PHBV-chitin nanocomposites and their foams. J. Polym. Environ. 2013, 22, 119-130. [CrossRef]

26. Rizvi, R.; Cochrane, B.; Naguib, H.; Lee, P.C. Fabrication and characterization of melt-blended polylactide-chitin composites and their foams. J. Cell. Plast. 2011, 47, 283-300. [CrossRef] 
27. Almasi, H.; Ghanbarzadeh, B.; Dehghannya, J.; Entezami, A.A.; Asl, A.K. Novel nanocomposites based on fatty acid modified cellulose nanofibers/poly(lactic acid): Morphological and physical properties. Food Packag. Shelf Life 2015, 5, 21-31. [CrossRef]

28. Reddy, M.M.; Vivekanandhan, S.; Misra, M.; Bhatia, S.K.; Mohanty, A.K. Biobased plastics and bionanocomposites: Current status and future opportunities. Prog. Polym. Sci. 2013, 38, 1653-1689. [CrossRef]

29. Frone, A.N.; Berlioz, S.; Chailan, J.-F.; Panaitescu, D.M.; Donescu, D. Cellulose fiber-reinforced polylactic acid. Polym. Compos. 2011, 32, 976-985. [CrossRef]

30. Tomé, L.C.; Pinto, R.J.B.; Trovatti, E.; Freire, C.S.R.; Silvestre, A.J.D.; Neto, C.P.; Gandini, A. Transparent bionanocomposites with improved properties prepared from acetylated bacterial cellulose and poly(lactic acid) through a simple approach. Green Chem. 2011, 13, 419-427. [CrossRef]

31. Abdulkhani, A.; Hosseinzadeh, J.; Ashori, A.; Dadashi, S.; Takzare, Z. Preparation and characterization of modified cellulose nanofibers reinforced polylactic acid nanocomposite. Polym. Test. 2014, 35, 73-79. [CrossRef]

32. Qu, P.; Zhou, Y.; Zhang, X.; Yao, S.; Zhang, L. Surface modification of cellulose nanofibrils for poly(lactic acid) composite application. J. Appl. Polym. Sci. 2012, 125, 3084-3091. [CrossRef]

33. Nakagaito, A.N.; Yamada, K.; Ifuku, S.; Morimoto, M.; Saimoto, H. Fabrication of Chitin Nanofiber-Reinforced Polylactic Acid Nanocomposites by an Environmentally Friendly Process. J. Biobased Mater. Bioenergy 2013, 7, 152-156. [CrossRef]

34. Zhang, Q.; Wei, S.; Huang, J.; Feng, J.; Chang, P.R. Effect of surface acetylated-chitin nanocrystals on structure and mechanical properties of poly(lactic acid). J. Appl. Polym. Sci. 2014, 131, 1-8. [CrossRef]

35. Li, X.; Liu, X.; Dong, W.; Feng, Q.; Cui, F.; Uo, M.; Akasaka, T.; Watari, F. In vitro evaluation of porous poly(L-lactic acid) scaffold reinforced by chitin fibers. J. Biomed. Mater. Res. B. Appl. Biomater. 2009, 90, 503-509. [CrossRef] [PubMed]

36. Arunraj, T.R.; Sanoj Rejinold, N.; Ashwin Kumar, N.; Jayakumar, R. Bio-responsive chitin-poly(L-lactic acid) composite nanogels for liver cancer. Colloids Surf. B Biointerfaces 2014, 113, 394-402. [CrossRef] [PubMed]

37. Robles, E.; Salaberria, A.M.; Herrera, R.; Fernandes, S.C.M.; Labidi, J. Self-bonded composite films based on cellulose nanofibers and chitin nanocrystals as antifungal materials. Carbohydr. Polym. 2016, 144, 41-49. [CrossRef] [PubMed]

38. Herrera, N.; Roch, H.; Salaberria, A.M.; Pino, M.A.; Labidi, J.; Fernandes, S.C.M.; Radic, D.; Leiva, A.; Oksman, K. Functionalized blown films of plasticized polylactic acid/chitin nanocomposite: Preparation and characterization. Mater. Des. 2015, 92, 846-852. [CrossRef]

39. Kasaai, M.R. Determination of the degree of N-acetylation for chitin and chitosan by various NMR spectroscopy techniques: A review. Carbohydr. Polym. 2010, 79, 801-810. [CrossRef]

40. Focher, B.; Beltrame, P.L.; Naggi, A.; Torri, G. Alkaline N-deacetylation of chitin enhanced by flash treatments recation kinetics and structure modifications. Carbohydr. Polym. 1990, 12, 405-418. [CrossRef]

41. Frisoni, G.; Baiardo, M.; Scandola, M.; Lednická, D.; Cnockaert, M.C.; Mergaert, J.; Swings, J. Natural cellulose fibers: Heterogeneous acetylation kinetics and biodegradation behavior. Biomacromolecules 2001, 2, 476-482. [CrossRef] [PubMed]

42. Freire, C.S.R.; Silvestre, A.J.D.; Neto, C.P.; Belgacem, M.N.; Gandini, A. Controlled heterogeneous modification of cellulose fibers with fatty acids: Effect of reaction conditions on the extent of esterification and fiber properties. J. Appl. Polym. Sci. 2006, 100, 1093-1102. [CrossRef]

43. Kumirska, J.; Czerwicka, M.; Kaczyński, Z.; Bychowska, A.; Brzozowski, K.; Thöming, J.; Stepnowski, P. Application of spectroscopic methods for structural analysis of chitin and chitosan. Mar. Drugs 2010, 8, 1567-1636. [CrossRef] [PubMed]

44. Owens, D.K.; Wendt, R.C. Estimation of the surface free energy of polymers. J. Appl. Polym. Sci. 1969, 13, 1741-1747. [CrossRef]

45. Ifuku, S.; Morooka, S.; Morimoto, M.; Saimoto, H. Acetylation of chitin nanofibers and their transparent nanocomposite films. Biomacromolecules 2010, 11, 1326-1330. [CrossRef] [PubMed]

46. Yoshifuji, A.; Noishiki, Y.; Wada, M.; Heux, L.; Kuga, S. Esterification of $\beta$-chitin via intercalation by carboxylic anhydrides. Biomacromolecules 2006, 7, 2878-2881. [CrossRef] [PubMed]

47. Wang, B.; Li, J.; Zhang, J.; Li, H.; Chen, P.; Gu, Q.; Wang, Z. Thermo-mechanical properties of the composite made of poly (3-hydroxybutyrate-CO-3-hydroxyvalerate) and acetylated chitin nanocrystals. Carbohydr. Polym. 2013, 95, 100-106. [CrossRef] [PubMed] 
48. Tomé, L.C.; Freire, M.G.; Rebelo, L.P.N.; Silvestre, A.J.D.; Neto, C.P.; Marrucho, I.M.; Freire, C.S.R. Surface hydrophobization of bacterial and vegetable cellulose fibers using ionic liquids as solvent media and catalysts. Green Chem. 2011, 13, 2464-2470. [CrossRef]

49. Pasquini, D.; Belgacem, M.N.; Gandini, A.; Curvelo, A.A.D.S. Surface esterification of cellulose fibers: Characterization by DRIFT and contact angle measurements. J. Colloid Interface Sci. 2006, 295, 79-83. [CrossRef] [PubMed]

50. Brugnerotto, J.; Lizardi, J.; Goycoolea, F.M.; Argüelles-Monal, W.; Desbrières, J.; Rianudo, M. An infrared investigation in relation with chitin and chitosan characterization. Polymer (Guildf) 2001, 42, 3569-3580. [CrossRef]

51. Gopalan Nair, K.; Dufresne, A. Crab shell chitin whisker reinforced natural rubber nanocomposites. 1. Processing and swelling behavior. Biomacromolecules 2003, 4, 657-665. [CrossRef] [PubMed]

52. Lee, K.-Y.; Quero, F.; Blaker, J.J.; Hill, C.A.S.; Eichhorn, S.J.; Bismarck, A. Surface only modification of bacterial cellulose nanofibres with organic acids. Cellulose 2011, 18, 595-605. [CrossRef]

53. Feng, F.; Liu, Y.; Hu, K. Influence of alkali-freezing treatment on the solid state structure of chitin. Carbohydr. Res. 2004, 339, 2321-2324. [CrossRef] [PubMed]

54. Muzzarelli, R.A.A.; Morganti, P.; Morganti, G.; Palombo, P.; Palombo, M.; Biagini, G.; Mattioli Belmonte, M.; Giantomassi, F.; Orlandi, F.; Muzzarelli, C. Chitin nanofibrils/chitosan glycolate composites as wound medicaments. Carbohydr. Polym. 2007, 70, 274-284. [CrossRef]

55. Chen, P.-Y.; Lin, A.Y.-M.; McKittrick, J.; Meyers, M.A. Structure and mechanical properties of crab exoskeletons. Acta Biomater. 2008, 4, 587-596. [CrossRef] [PubMed]

56. Choi, C.; Kim, S.; Pak, P.; Yoo, D.; Chung, Y. Effect of N-acylation on structure and properties of chitosan fibers. Carbohydr. Polym. 2007, 68, 122-127. [CrossRef]

57. Li, J.; Zhang, L.-P.; Peng, F.; Bian, J.; Yuan, T.-Q.; Xu, F.; Sun, R.-C. Microwave-assisted solvent-free acetylation of cellulose with acetic anhydride in the presence of iodine as a catalyst. Molecules 2009, 14, 3551-3566. [CrossRef] [PubMed]

58. Cunha, A.G.; Fernandes, S.C.M.; Freire, C.S.R.; Silvestre, A.J.D.; Neto, C.P.; Gandini, A. What Is the Real Value of Chitosan's Surface Energy? Biomacromolecules 2008, 9, 610-614. [CrossRef] [PubMed]

59. Gopalan Nair, K.; Dufresne, A.; Gandini, A.; Belgacem, M.N. Crab shell chitin whiskers reinforced natural rubber nanocomposites. 3. Effect of chemical modification of chitin whiskers. Biomacromolecules 2003, 4, 1835-1842. [CrossRef] [PubMed]

60. Ruseckaite, R.A.; Martino, V.P.; Jiménez, A. Processing and characterization of poly(lactic acid) films plasticized with commercial adipates. J. Appl. Polym. Sci. 2009, 112, 2010-2018. [CrossRef]

61. Jamshidian, M.; Tehrany, E.A.; Imran, M.; Akhtar, M.J.; Cleymand, F.; Desobry, S. Structural, mechanical and barrier properties of active PLA-antioxidant films. J. Food Eng. 2012, 110, 380-389. [CrossRef]

62. Zakaria, Z.; Effatin, S.; Mohd, A.; Hassan, A. Effects of chitin nanowhiskers on tensile properties of polylactic acid biocomposite film. In Proceedings of the 16th European Conference on Composite Materials, Seville, Spain, 22-26 June 2014.

63. Mohd Asri, S.E.A.; Zakaria, Z.; Hassan, A.; Mohamad Haafiz, M.K. Mechanical properties of polylactic acid/treated fermented chitin nanowhiskers biocomposites. Appl. Mech. Mater. 2014, 606, 89-92. [CrossRef]

64. Issam, S.; Adele, M.-G.; Adele, C.-P.; Grelier, S.; Coma, V. Chitosan polymer as bioactive coating and film against Aspergillus niger contamination. J. Food Sci. 2005, 70, 100-104. [CrossRef]

65. Rabea, E.I.; Badawy, M.E.-T.; Stevens, C.V.; Smagghe, G.; Steurbaut, W. Chitosan as antimicrobial agent: applications and mode of action. Biomacromolecules 2003, 4, 1457-1465. [CrossRef] [PubMed]

66. Kong, L.A.; Yang, J.; Li, G.T.; Qi, L.L.; Zhang, Y.J.; Wang, C.F.; Zhao, W.S.; Xu, J.R.; Peng, Y.L. Different chitin synthase genes are required for various developmental and plant infection processes in the rice blast fungus Magnaporthe oryzae. PLoS Pathog. 2012, 8, 1-16. [CrossRef] [PubMed]

67. Krajewska, B.; Kyzioł, A.; Wydro, P. Colloids and surfaces A: Physicochemical and engineering aspects chitosan as a subphase disturbant of membrane lipid monolayers. The effect of temperature at varying $\mathrm{pH}$ : II. DPPC and cholesterol. Colloids Surf. A Physicochem. Eng. Asp. 2013, 434, 359-364. [CrossRef] 